INDEPENDENT JOURNAL OF MANAGEMENT \& PRODUCTION (IJM\&P)

http://www.ijmp.jor.br

v. 8, n. 1, January - March 2017

ISSN: 2236-269X

DOI: 10.14807/ijmp.v8i1.520

\title{
HAEMOPROTOZOA INFECTION OF DOMESTIC BIRDS IN HILLY \\ AREAS OF BANGLADESH
}

Tilak Chandra Nath

Faculty of Veterinary and Animal Science, Sylhet Agricultural

University, Bangladesh

E-mail: tilak.parasitology@sau.ac.bd

Md. Jamal Uddin Bhuiyan Faculty of Veterinary and Animal Science, Sylhet Agricultural

University, Bangladesh

E-mail: bhuiyanmju.dpp@sau.ac.bd

Submission: $25 / 07 / 2016$

Accept: 01/08/2016

\section{ABSTRACT}

The blood protozoa of two important domestic birds namely chickens (Gallus domesticus) and pigeon (Columba livia) reared in the hilly areas of Bangladesh were studied. A total of 400 birds (200 chicken and 200 pigeons) were examined of which $149(37.3 \%)[95 \% \mathrm{Cl}]$ birds were found infected by one or more haemoprotozoan parasites. Haemoprotozoa belonging to three genera were identified. Pigeon 80 (40\%) was recorded more susceptible to haemoprotozoa infection than chicken 69 (34.5\%). 118 birds (29.5\%) were found to be infected with single infection where as mixed infections were found in 31 birds (7.8\%). The prevalence of blood protozoa in female birds (69.5\%) was found significantly higher $(p \leq 0.0001)[95 \% \mathrm{Cl}]$ than male birds (5\%). Within the study period, the prevalence rate of Haemoprotozoa was $60.6 \%$ in summer season, $36.7 \%$ in rainy and $23 \%$ winter seasons. This study has archived a high prevalence of haemoparasites, henceforth encourage further to determine the effect of contamination on the productivity and profitability of these birds, and evaluation of cost-benefit of various control strategies need to be undertaken.

Keywords: Prevalence, Haemoproteus, Plasmodium,Leucocytozoon 
DOI: 10.14807/ijmp.v8i1.520

\section{INTRODUCTION}

Bangladesh is a developing nation where poultry industry is a rising sector. Being an integrated part of the livestock sector, poultry farming plays an important role in the agro-based economy of Bangladesh (MINISTRY OF LIVESTOCK; FISHERIES, 2012). The increasing demand for animal protein and the economic benefit obtained through raising of poultry in both scavenging and semi-scavenging condition have created a great deal of interest among the farmers in this country (LATIF, 2001). Poultry keeping is one of the most appropriate income generating activities for rural women especially for landless and marginal farmers which employs about 5 million people (BLRI, 2015).

Poultry production in Bangladesh specifically includes chickens, pigeon, ducks, quail, swan and guinea fowl. Chicken and Pigeon productions however, make up the main component of the commercial poultry. The production of backyard chicken and pigeon under the semi-scavenging system is found suitable to the villagers as an additional source of income and nutrient supplement (LATIF, 2001). The total population of poultry in our country is about 252.31 million where the chicken population is 256.78 million. However, there is no definite statistics in pigeon population (BLRI, 2015).

Several health problems can affect chicken and pigeon, but parasitic infections play a major role. Blood parasites have been the subject of extensive research since the beginning of the 20th century. Haemoprotozoa infection is common in the domestic birds but poorly studied in Bangladesh (THE RAFFLES BULLETIN OF ZOOLOGY, 2008). Some researchers reported haemoprotozoa of different species in poultry in Bangladesh (MOMIN, 2014; DEY et al., 2010).

But the number of work regarding distribution or prevalence of these parasites is very limited. Such information is crucial in the implementation of a disease control programme hence improvements in the productivity of indigenous free-ranging chicken and pigeon. This study is designed and conducted to investigate the type and prevalence of haemoparasites infection in indigenous freeranging chickens, and pigeon in different hilly areas in Bangladesh, and the data will assist in identifying the host infectivity prevalence and contribute to a long term database on the occurrence of these parasites. 
DOI: 10.14807/ijmp.v8i1.520

\section{MATERIALS AND METHODS}

A total of 400 birds (200 indigenous chickens and 200 pigeons) with matching for sex were purposively randomly selected from four (4) different hilly districts of Bangladesh (Sylhet, Hobigonj, Khagrachari and Bandarban) during January to December 2014.

Sex was determined subjectively based on the length of spur and flexibility of the xiphoid cartilage together with information from the farmers. Three (3) thin blood smears were prepared from each bird, processed and examined for haemoprotozoa. Blood collection samples from same chickens and pigeon were collected from the wing vein using a $1 \mathrm{ml}$ syringe. The skin was hosed with alcohol to disinfect the area and make the vein noticeable.

The blood was straightforwardly transferred into labelled test tubes containing anticoagulant (EDTA) and transported to the Laboratory of Parasitology, Faculty of Veterinary and Animal Science, Sylhet Agricultural University, Bangladesh for staining and identification. In the laboratory, blood samples were processed using thin blood smear to detect and identify parasites. A drop of blood was put on a clean grease free glass slide.

A thin smear was made and allowed to dry. It was then fixed in alcohol and then stained with Giemsa stain. Slides were subjected to a microscopic examination and result was recorded. Haemoparasites were identified according to guidelines described by Levine (1985) and Soulsby (1982). The specific data was collected directly from the farmer by a structured questionnaire. The data was analyzed using STATA-13 statistical package. The association between sex and infection status was evaluated using the chi-squared test. A $p$ value less than 0.05 was considered statistically significant.

\section{RESULTS}

The research showed that out of the 400 birds examined, 149 (37.3\%) were infected with at least one out of three species of Haemoprotozoa. The study revealed a significant difference between haemoparasite species values either single or mixed infected in both chicken and pigeon ( $p \leq 0.003$ ) with no significant difference between species of birds ( $p \leq 0.139)$ with the highest value for Pigeon $80(40 \%)$ followed by Chicken 69 (34.5\%). Some of the birds were singly infected while others 
INDEPENDENT JOURNAL OF MANAGEMENT \& PRODUCTION (IJM\&P)

http://www.ijmp.jor.br

v. 8, n. 1, January - March 2017

ISSN: 2236-269X

DOI: 10.14807/ijmp.v8i1.520

had multiple infections. Chicken higher prevalence of Leucocytozoon species whereas Pigeon had a higher infection with Haemoproteus species (table 1).

In chicken, three genera of Haemoparasites comprising Haemoproteus spp 5 (2.5\%), Plasmodium spp 21 (10.5\%), and Leucocytozoon spp 29 (14.5\%) was found, while non-infected birds were 131 (65.5\%) (Table-1). Mixed infection was recorded comprising Plasmodium spp and Leucocytozoon spp 13(6.5\%) and Plasmodium spp and Haemoproteus spp 1 (0.5\%).

No triple infection (Plasmodium spp + Heamoproteus spp + Leucocytozoon spp) was found in case of chicken. In pigeon, infection with Haemoproteus spp was more prevalent 49 (24.5\%) followed by infection with Plasmodium spp 11 (5.5\%). Only $3(1.5 \%)$ cases of Leucocytozoon was recorded. For the double infection, Plasmodium spp and Haemoproteus spp 9 (4.5\%), Haemoproteus spp and Leucocytozoon spp 2 (1\%) and Plasmodium spp and Leucocytozoon spp 1 (0.5\%) while for triple infection (Plasmodium spp + Heamoproteus spp + Leucocytozoon spp), was 5 (2.5\%) (Table-1).

Table 1: Prevalence of Haemoprotozoa in Chicken \& Pigeon (single or mixed infection)

\begin{tabular}{|c|c|c|c|c|}
\hline Species & $\begin{array}{c}\text { Haemoprotozoa } \\
\text { occurrence in birds* }\end{array}$ & $\begin{array}{l}\text { Number of birds } \\
\text { infected with } \\
\text { Haemoprotozoa }\end{array}$ & $\begin{array}{c}\text { Percentage } \\
\text { prevalence rate } \\
(\%)\end{array}$ & $\begin{array}{c}\text { Overall } \\
\text { Prevalence } \\
(n=400)\end{array}$ \\
\hline \multirow{7}{*}{$\begin{array}{l}\text { Chicken } \\
(n=200)\end{array}$} & Only P & 21 & 10.5 & \multirow{7}{*}{$34.5 \%$} \\
\hline & Only L & 29 & 14.5 & \\
\hline & Only H & 5 & 2.5 & \\
\hline & Both $\mathrm{P}+\mathrm{L}$ & 13 & 6.5 & \\
\hline & Both $\mathrm{P}+\mathrm{H}$ & 1 & 0.5 & \\
\hline & Both $\mathrm{L}+\mathrm{H}$ & 0 & 0 & \\
\hline & Triple $\mathrm{H}+\mathrm{P}+\mathrm{L}$ & 0 & 0 & \\
\hline \multirow{7}{*}{$\begin{array}{l}\text { Pigeon } \\
(n=200)\end{array}$} & Only P & 11 & 5.5 & \multirow{7}{*}{$40 \%$} \\
\hline & Only L & 3 & 1.5 & \\
\hline & Only H & 49 & 24.5 & \\
\hline & Both $\mathrm{P}+\mathrm{L}$ & 1 & 0.5 & \\
\hline & Both $\mathrm{P}+\mathrm{H}$ & 9 & 4.5 & \\
\hline & Both $\mathrm{L}+\mathrm{H}$ & 2 & 1 & \\
\hline & Triple $\mathrm{H}+\mathrm{P}+\mathrm{L}$ & 5 & 2.5 & \\
\hline
\end{tabular}

${ }^{*} \mathrm{P}=$ Plasmodium spp., L=Leucocytozoon spp., $\mathrm{H}=$ Haemoproteus spp.

The results of haemoprotozoa infections of the chickens according to their sexes and season are presented in table 2. Regarding the sex of infected birds, results showed that female birds were more infected 139 (69.5\%) than males 10 $(5 \%)$ with significant difference $(p \leq 0.0001)$. No significant difference was found between positive seasonal cases distribution ( $p \geq 0.067$ ), which shows infections in 
INDEPENDENT JOURNAL OF MANAGEMENT \& PRODUCTION (IJM\&P)

http://www.ijmp.jor.br

v. 8, n. 1, January - March 2017

ISSN: 2236-269X

DOI: 10.14807/ijmp.v8i1.520

summer 91 (60.6\%) was the highest than rainy $55(36.7 \%)$ followed by winter 23 (23\%) (Table-2).

Table 2: Prevalence of Haemoprotozoa According to Sex and Seasonal Condition

\begin{tabular}{|l|l|c|c|}
\hline Variable & Sex and Season & $\begin{array}{c}\text { Number of birds infected } \\
\text { with Haemoprotozoa }\end{array}$ & $\begin{array}{c}\text { No. (\%) infected with } \\
\text { Haemoprotozoa }\end{array}$ \\
\hline \multirow{3}{*}{ Chicken } & Male $(\mathrm{n}=100)$ & 7 & 7 \\
\cline { 2 - 4 } & Female(n=100) & 62 & 62 \\
\hline \multirow{3}{*}{ Oigeon } & Male $(\mathrm{n}=100)$ & 3 & 3 \\
\cline { 2 - 4 } & Female $(\mathrm{n}=100)$ & 77 & 22 \\
\hline \multirow{3}{*}{ Season } & Male $(\mathrm{n}=200)$ & 10 & 5 \\
\cline { 2 - 4 } & Female $(\mathrm{n}=200)$ & 139 & 69.5 \\
\cline { 2 - 4 } & Summer $(\mathrm{n}=150)$ & 91 & 60.6 \\
\cline { 2 - 4 } & Rainy $(\mathrm{n}=150)$ & 55 & 36.7 \\
\cline { 2 - 4 } & Winter $(\mathrm{n}=100)$ & 23 & 23 \\
\hline
\end{tabular}

4. DISCUSSION:

Haemoprotozoa is continuously circulating around the universe. Prevalence of haemoparaites was reported high in human in hilly areas of Bangladesh but a review of the literature did not give prior information as regards the prevalence of haemoparasites in birds. Results obtained from this study exposed the presence of three haemoparasites (Plasmodium spp, Leucocytozoon spp and Haemoproteus spp) that were found to infect both chicken and pigeon in the study areas.

Mixed infections of these haemoparasites were also found. The findings of this study are supported by the study of Tiwari et al. (2012) in West Indies, Dey et al. (2010) in Bangladesh and Sadiq et al. (2003) in Nigeria, they reported the same three haemoprotozoa (Plasmodium spp, Leucocytozoon spp and Haemoproteus spp) during their study. Similar findings were also reported by Permin et al. (2002) in Zimbabwe, Bennett et al. (1975) in Nova Scotia and Gulanber et al. (2002) in Istanbul.

Prevalence of haemoparasites in birds in this study was found to be $37.3 \%$. These findings are below than the findings of previous studies done by Valkiûnas et al. (2005) who documented the prevalence of avian blood parasites in Uganda to be $61.9 \%$, and Njunga et al. (2003) in Malawi found the prevalence of haemoparasites in birds to be $71 \%$. Their reported prevalence was higher, likely because they used molecular methods to detect parasites, which are known to be more sensitive. Another reason for this variation might be due to the variation in the geographical distribution, climatic condition, management system of poultry, and availability of vector. 
INDEPENDENT JOURNAL OF MANAGEMENT \& PRODUCTION (IJM\&P)

http://www.ijmp.jor.br

v. 8, n. 1, January - March 2017

ISSN: 2236-269X

DOI: 10.14807/ijmp.v8i1.520

Variations in the prevalence of infection in different bird families have been reported in this study. Pigeon harbors more haemoprotozoa than chicken. Mixed occurrence of blood parasite was also high in pigeons in compared to chicken. Momin (2014) also reported almost similar result during his investigation of blood protozoa in poultry in Tangail, Bangladesh. The difference in the prevalence may involve behavioral perspective or some physiological conditions characteristic for the species that may make the host more or less vulnerable to the parasites (Elahi et al, 2014; NATH et al, 2014).

In the present study, there were no significance differences in occurrences among chicken and pigeon but a significant association between sex and haemoprotozoa infection was detected. Senlik et al. (2005) were unable to detect a significant difference in the infection rate of this parasite in terms of host sex. However, the reason for different prevalence across bird's sexes was not clear because there were no documented studies on the comparisons between sexes, hence should be studied further.

In this study, the prevalence of Leukocytozoon was found higher in chicken than pigeon. Very few data is available to explain the prevalence of Leukocytozoon in chickens as well as pigeons. Mamud et al. (2012) in Nigeria reported the prevalence of Leukocytozoon in pigeon was 3\% while Mbuthia et al. (2011) in Kenya reported $31.6 \%$ of Leucocytozoon in chicken.

The high prevalence of Plasmodium in Chicken was detected in compare to Pigeon which are supported by the study carried out by Mamud et al. (2012) in Nigeria, Mbuthia et al (2011) in Kenya, Akinpelu (2008) in Africa, Sehgal et al. (2006) in Ivorycoast and Valkiunas et al. (2004) in Northwestern Costa Rica. Mamud et al. (2012) in Nigeria reported 30\% prevalence of Plasmodium in pigeon while Mbuthia et al. (2011) in Kenya reported $29.8 \%$ of Plasmodium in chicken. The higher prevalence of Plasmodium was possibly due to the high abundance of its vectors (mosquito) in the study areas.

The prevalence of Haemoproteus found in this study was higher in pigeon than chicken. These findings are supported by the findings of Tiwari et al. (2012), Mamud et al. (2012), Mbuthia et al. (2011), Permin et al. (2002) and Sehgal et al. (2005). 
This study was also conducted throughout the year where higher prevalence was recorded during the summer season which provides a very conducive environment for the breeding and proliferation of the arthropod vectors (OLAYEMI et al. 2014). The mosquito breeding rate generally is high during summer season in Bangladesh. This important role of seasonal impact on vector and the haemoparasite spread could be used as a vital tool in the institution of preventive and control measures for both chicken and pigeon.

Apart from rainfall and differences in habitat composition, differences in prevalence may be influenced by proximity to breeding for vectors, relative levels of host resistance, local temperature differences, time of collection during the day and age of host among the others (OLAYEMI et al, 2014; NATH et al, 2014).

\section{CONCLUSION}

Three genera of blood parasites were present, which include Haemoproteus, Plasmodium, and Leucocytozoon. This study documented that there is a high prevalence of haemoprotozoa infection in apperantly healthy looking indigenous chicken and pigeon. However, further study with a greater sample size is necessary to assess the intensity of the infection more accurately.

Predisposing factors to haemoprotozoa infection also need to be examined. What's more, the only tests used in this study was microscopy which has a very limited specificity, and therefore more obtrusive tests need to be used. Identification of different species of this blood protozoon among chicken and pigeon not only will generate knowledge but also help in developing strategies for successful control programs.

\section{ETHICAL APPROVAL}

Approval for this study was obtained from the Department of Parasitology, Faculty of Veterinary and Animal Science, Sylhet Agricultural University, Bangladesh before the implementation of the study. Birds were extracted from the traps as soon as possible after collecting blood sample. All the samples were collected by the corresponding author (registered veterinarians). Blood collected from each bird was less than $1 \%$ of the body weight. 
DOI: 10.14807/ijmp.v8i1.520

\section{ACKNOWLEDGEMENTS}

The authors wish to acknowledge Dr. Shafiul Alam, Associate Scientist, International Centre for Diarrheal Disease Research, Bangladesh for his guidance, contribution and logistic supports during the course of this study. Local guides and smallholder farmers from various villages in Chittagong and Sylhet division where the samples were collected are appreciated for their indefatigable support and cooperation while sourcing for the study material.

\section{COMPETING INTERESTS}

There is no conflict of interest declared by any of the authors.

\section{AUTHOR CONTRIBUTIONS}

The study was supervised by Md. Jamal Uddin Bhuiyan while the design of the study, field experiments, data analysis and writing of the manuscript was performed by Tilak Chandra Nath.

\section{REFERENCES}

AKINPELU, A. I. (2008) Prevalence and intensity of blood parasites in wild pigeons and Chicken. Science Alert Journal. n. 109, p. 114

BENNETT, G. F.; BORRERO, J. I. (1976) Blood parasites of some birds from Colombia. Journal of Wildlife Disease, v. 12, n. 3, p. 454-8.

BLRI (Bangladesh Livestock Research Institude) report. (2015) www.blri.gov.bd DEY, A. R.; BEGUM, N.; PAUL, S. C.; NOOR, M.; ISLAM, K. M. (2008) Prevalence and pathology of blood protozoa in duck. Bangl. J. Vet. Med, v. 6, n. 1, p. 53-58

ELAHI, R.; ISLAM, A.; HOSSAIN, M. S.; MOHIUDDIN, K.; MIKOLON, A.; PAUL, S. K.; HOSSEINI, P. R.; DASZAK, P.; ALAM, M. S. (2014) Prevalence and diversity of avian haematozoan parasites in wetlands of Bangladesh. Journal of Parasitological Research. 2014, p. 1-12.

GULANBER, A.; TUZER, E.; CETINKAYA, H. (2002) Haemoproteus columbae infections and Pseudolynchia canariensis infestations in pigeons in Istanbul, Turkey. Veteriner Fakultesi Dergisi Istanbul, v. 28, n. 1, p. 227-229.

LATIF, M. A. (2001) Development strategies of livestock and poultry in Bangladesh. Proceedings of the International Poultry Show. World's Poultry Science Association, Bangladesh: p. 27-33.

LEVINE, N. D. (1985) Veterinary Parasitology. $1^{\text {st }}$ Edition. Iowa State University Press, USA. 266-282.

MAMUD, N. J.; KABIR, M. A.; DIBAL, D. M.; RAJAB, M. H. (2011) Study on the Prevalence of Haemoparasites of Pigeon (Columba livia) In Lapai-Nigeria. International Journal of Applied Biological Research, v. 4, n. 1/2, p. 121-127 
MANDAL, F. B. (1990) Seasonal incidence of blood-inhabiting Haemoproteus columbae Kruse (Sporozoa: Haemoproteidae) in pigeons. Indian Journal of Animal Health, v. 29, n. 1, p. 29-35.

MBUTHIA, P. G.; SABUNI, Z. A.; MAINGI, N.; NYAGA, P. N.; MICHIEKA, J. N. (2011) Prevalence of haemoparasites infection in indigenous chicken in Eastern Province of Kenya. Livestock Research for Rural Development, n. 23, p.11-19.

MOMIN, A. (2014) Prevalence of Blood Protozoa in Poultry in Tangail. MS Thesis. Bangladesh Agricultural University, Bangladesh.

NATH, T. C.; BHUIYAN, M. J. U.; ALAM, M. S. (2014) A study on the presence of leucocytozoonosis in pigeon and chicken of hilly districts of Bangladesh. Issues in Biological Sciences and Pharmaceutical Research, v. 2, n. 2, p. 13-18.

NJUNGA, G. R. (2003) Ecto- and haemoparasites of chicken in Malawi with emphasis on the effects of the chicken louse, Menacanthus cornutus. MSc Thesis. The Royal Veterinary and Agriculture University, Denmark.

OLAYEMI, O. A.; JUBRIL, A. J.; ADEKOLA, A. (2014) Prevalence of Haemoparasites in Village Weaver in Ibadan, Nigeria. J. World's Poult. Res, v. 4, n. 4, p. 89-93

PERMIN, A.; ESMANN, J. B.; HOJ, C. H.; HOVE, T.; MUKATIRWA, S. (2002) Ecto-, Endo- and Haemoparasites in free range chicken in the Gomoronzi District in Zimbabwe. Preventive Veterinary Medicine, n. 54, p. 213-224.

SADIQ, N. A.; ADEJINMI, J. O.; ADEDOKUN, O. A.; FASHANU, S. O.; ALIMI, A. A.; SOFUNMADE, Y. T. (2003) Ectoparasites and haemoparasites of indigenous chicken (Gallus domesticus) in Ibadan and environs. Tropical Veterinarian, n. 21, p. 187-191.

SEHGAL, R. N. M.; GEDIMINAS, V.; TATJANA, A. L.; SMITH, T. B. (2006) Blood parasites of chickens in Uganda and Cameroon. Journal of Parasitology, n. 92, p. 1336-1343.

SENLIK, B.; GULEGEN, E.; AKYOL, V. (2005) Prevalence and intensity of Haemoproteus columbae in domestic pigeons. Indian Veterinary Journal, v. 82, n. 9, p. 998-999.

SOULSBY, E. J. L. (1982) Helminth, Arthropods and Protozoa of Domesticated Animals. $7^{\text {th }}$ Edition. Baillire, Tindall. 35-740.

THE RAFFLES BULLETIN OF ZOOLOGY. (2008) www.icddrb.org/zoology

VALKIUNAS, G.; IEZHOVA, T. A.; BROOKS, D. R.; HANELT, B.; BRANT, S.V.; SUTHERLIN, M. E.; CAUSEY, D. (2004) Additional observations on blood parasites of birds in Costa Rica. Journal of Wildlife Disease, v. 40, n. 3, p. 555-61.

TIWARI, K. P.; CHIKWETO, A.; KUMTHEKAR, S. (2012) Prevalence of haemoparasites in backyard poultry and wild pigeons of Grenada, West Indies. Indian Journal of Animal Research, v. 2, n. 3, p. 209-213 